Wojciech Filipkowski

\title{
NOWE KIERUNKI BADAŃ NAD BEZPIECZEŃSTWEM W POLSCE I ICH EFEKTY
}

\section{Uwagi wstępne}

Bezpieczeństwo jest dobrem społecznym i prawnym o doniosłym znaczeniu. Jako członkowie społeczeństwa potrzebujemy poczucia, że prawdopodobieństwo występowania jakichkolwiek zagrożeń jest niskie dzięki aktywności powołanych do tego organów państwowych, jak i działań niemających tak zinstytucjonalizowanej postaci. Zapewnienie bezpieczeństwa jest jednym z podstawowych celów istnienia państwa ${ }^{1}$. Jest to też jeden z warunków koniecznych, aby społeczeństwo mogło rozwijać się pod względem gospodarczym, naukowym, obywatelskim czy artystycznym.

Samo pojęcie bezpieczeństwa ma wiele znaczeń i odmian². Charakterystyczne jest to, że przedstawiciele poszczególnych dziedzin nauki mają własne spojrzenie na to pojęcie i często ograniczają się do tego jednego - ich zdaniem najważniejszego znaczenia. Ponadto, na jego definiowanie mają wpływ same zagrożenia. Współcześnie społeczeństwo musi borykać się z nowymi zagrożeniami, które nie występowały wcześniej lub czyniły z mniejszą intensywnością. Z różną mocą możemy - jako społeczeństwo i państwo - oddziaływać na zagrożenia, dążąc do ich kontrolowania, minimalizowania czy też rzadziej całkowitej likwidacji.

Dlatego też jest to niezwykle ciekawy obszar do prowadzenia różnorodnych badań naukowych ${ }^{3}$. Zostało to dostrzeżone w kontekście zarówno krajowym jak i regionalnym. Świadczą o tym działania podejmowane przez poszczególne ośrodki akademickie, instytuty badawcze, ale także instytucje międzynarodowe, np. Unię

$1 \quad$ Na przykład art. 5. Konstytucji RP stanowi, iż Rzeczpospolita Polska zapewnia bezpieczeństwo obywateli.

2 Por. M. Brzeziński, Rodzaje bezpieczeństwa państwa, (w:) S. Sulowski, M. Brzeziński (red.), Bezpieczeństwo wewnętrzne państwa. Wybrane zagadnienia, Warszawa 2009, s. 34; Z. Nowakowski, H. Szafran, R. Szafran, Bezpieczeństwo w XXI wieku, Rzeszów 2009, s. 72 oraz W. Prokruszyński, Uwarunkowania współczesnego bezpieczeństwa międzynarodowego, Szczytno 2006, s. 9 i nast.

3 O wielu aspektach badań nad bezpieczeństwem narodowym, zob. P. Sienkiewicz, M. Marszałek, H. Świeboda (red.), Metodologia badań bezpieczeństwa narodowego. Bezpieczeństwo 2010, t. II, Warszawa 2011. 
Europejską ${ }^{4}$. Mamy szereg przykładów inicjatyw i projektów w tym obszarze. W tym miejscu należy wymienić sieć uniwersytecka, Polską Platformę Bezpieczeństwa Wewnętrznego ${ }^{5}$. Ponadto kwestia bezpieczeństwo jest jednym z priorytetów Polskiej Prezydencji w Radzie Unii Europejskiej ${ }^{6}$.

W ramach prac prowadzonych na Wydziale Prawa Uniwersytetu w Białymstoku, Katedrze Prawa Karnego zespół badawczy zajmuje się przede wszystkim badaniami nad bezpieczeństwem wewnętrznym, powiązanym ściśle z zapewnieniem porządku publicznego oraz wymiarem sprawiedliwości ${ }^{7}$. Z racji zainteresowań naukowych oraz doświadczeń badania są prowadzone w obszarze rozważań prawnych, kryminologicznych oraz kryminalistycznych. Z tego też punktu widzenia zostaną zaprezentowane nowe kierunki badań nad bezpieczeństwem w Polsce i ich efekty.

\section{Prezentacja projektów badawczych}

Pierwszy projekt dotyczący bezpieczeństwa - realizowany na Wydziale Prawa Uniwersytetu w Białymstoku - był zatytułowany „Rozwiązania prawne i organizacyjno-techniczne w zwalczaniu przestępczości zorganizowanej oraz terroryzmu ze szczególnym uwzględnieniem problematyki dowodów procesowych oraz instytucji świadka koronnego" (Nr PBZ-MIN-004/T00/2002)․ Był to projekt badawczy zamawiany Ministerstwa Nauki i Szkolnictwa Wyższego.

Założenia projektu badawczego przewidywały obszerną analizę sposobów walki z dwoma najpoważniejszymi wtedy zagrożeniami bezpieczeństwa obywateli, czyli przestępczością zorganizowaną oraz terroryzmem. Analiza miała dotyczyć przede wszystkim aspektów prawnych, organizacyjnych i kryminologicznych. Badania kładły szczególny nacisk na aspekt praktyczny stosowania ich wyników.

Podczas realizacji projektu przeprowadzono badania aktowe, m.in. kilku tysięcy tomów akt spraw karnych przeciwko członkom zorganizowanych grup przestępczych prowadzonych we wszystkich fazach postępowania karnego: postępowania przygotowawczego oraz sądowego, jak również wykonania orzeczonych kar pozbawienia wolności oraz pracy operacyjnej, co stanowiło nowość w Polsce. Poddanie

\footnotetext{
$4 \quad$ Na uwagę zasługuje 7. Program Ramowy, gdzie bezpieczeństwo jest jednym z promowanych obszarów badań. Z jego ramach powstały takie projekty jak INDECT (strona internetowa projektu http://www.indect-project.eu/) i DETECTER (strona internetowa projektu http://www.detecter.bham.ac.uk/).

5 Szerzej na ten temat, zob. E.W. Pływaczewski, Z. Rau, The Polish Platform for Homeland Security - a Pionier Initiative for Up-to-date Security in the European Union, (w:) E.W. Pływaczewski (red.), Current Problems of the Penal Law and Criminology, Białystok 2009, s. 445 i nast. oraz oficjalną stronę internetową http://www.ppbw.pl

6 Oficjalna strona internetowa Polskiej Prezydencji w Unii Europejskiej: http://pl2011.eu/program_and_priorities

7 Szerzej na ten temat zob. E.W. Pływaczewski, K. Laskowska, G.B. Szczygieł, E.M. Guzik-Makaruk, E. Zatyka, W. Filipkowski, Polskie kierunki badań kryminologicznych nad bezpieczeństwem obywateli, „Prokuratura i Prawo" 2010, nr 1-2, s. 176 i nast.

8 Realizowany w latach 2003-2006 pod kierunkiem prof. zw. dr hab. E.W. Pływaczewskiego.
} 
wyników tych badań ocenie praktyków organów ścigania i wymiaru sprawiedliwości pozwoliło na diagnozę istniejących oraz ocenę proponowanych rozwiązań prawnych. Zwrócono uwagę na efektywne wykorzystanie instytucji świadka koronnego oraz zagadnienie implementacji materiału uzyskanego w trakcie czynności operacyjnych do procesu karnego.

Podczas realizacji projektu dokonano całościowej analizy istniejących regulacji prawnych dotyczących instytucji świadka koronnego. Opisano specyfikę postępowania przygotowawczego oraz sądowego z jego udziałem na podstawie akt spraw karnych. Poddano analizie również jego status w procesie - prawa i obowiązki względem innych osób oraz państwa, m.in. w zakresie prawa cywilnego, rodzinnego, podatkowego. Ponadto zbadane zostały sprawy karne pod kątem przydatności tej instytucji oraz wiarygodności dostarczanych przez nią dowodów. Wyniki analizy - poparte szeroką dyskusją z praktykami wymiaru sprawiedliwości i organów ścigania - doprowadziły do przygotowania projektu zmian Ustawy o świadku koronnym, które po przeprowadzeniu prac parlamentarnych weszły w życie9 9

Kolejnym zakresem badawczym było zjawisko korupcji. Zostało ono potraktowane wieloaspektowo. Analizie poddane zostało m.in. korupcyjne oddziaływanie przestępczości zorganizowanej na struktury państwowe, gospodarcze oraz samorządowe. Za pewne novum należy uznać przeprowadzenie badań dotyczących zjawiska korupcji w szeroko rozumianym wymiarze sprawiedliwości, a także roli obrońców w tym procederze. Przedstawione zostały nie tylko wyniki badań, ale także konkretne postulaty zmian prawa i praktyki w tym zakresie.

Ważnym obszarem badań było zjawisko zorganizowanej przestępczości rosyjskojęzycznej w Polsce i krajach ościennych. Pozwoliło to na ocenę stopnia zagrożenia z jej strony dla bezpieczeństwa państwa i obywateli. Ponadto przeprowadzono na szeroką skalę nowatorskie badania dotyczące wykonywania kary pozbawienia wolności przez osoby skazane za udział w zorganizowanej przestępczości. Zwalczanie przestępczości zorganizowanej w aspekcie finansowym (zjawisko prania pieniędzy) również było przedmiotem badań. Wskazano na związki tego zjawiska z finansowaniem terroryzmu pod względem stosowanych metod oraz uczestników obu procederów.

Kolejnym obszarem badawczym był terroryzm, który odcisnął współcześnie największe piętno w świadomości ludzkiej. Także i w tym przypadku przeprowadzone badania miały charakter wielowątkowy, poczynając od diagnozy różnego rodzaju zagrożeń, poprzez oddziaływanie socjotechniczne terrorystów na społeczeństwo, wykorzystania mediów elektronicznych, aż po istniejące i proponowane instytucje prawne, zasady odpowiedzialności i problematykę dowodową w tym 
zakresie. Ocenie podlegało także znaczenie i przydatność nowych rozwiązań technicznych $\mathrm{i}$ informatycznych zarówno $\mathrm{w}$ walce $\mathrm{z}$ przestępczością zorganizowaną jak i terroryzmem. Wskazano również, iż praca operacyjna organów ścigania ma zasadnicze znaczenie dla przeciwdziałania tym zagrożeniom, chociaż miała swoją specyfikę typową dla działań podejmowanych przez służby specjalne.

Bilans całego projektu można zamknąć w następujących liczbach: 12 konferencji, w tym 3 międzynarodowe; 70 referatów, 10 monografii i prac zbiorowych, 159 artykułów (w tym 31 obcojęzycznych) oraz 20 innych opracowań ${ }^{10}$.

Projekt badawczy zamawiany Ministerstwa Nauki i Szkolnictwa Wyższego pt. „Monitoring, identyfikacja i przeciwdziałanie zagrożeniom bezpieczeństwa obywateli” (Nr PBZ-MNiSW-DBO-01/I/2007) ${ }^{11}$ był drugim z zakresu bezpieczeństwa, tym razem realizowanym w konsorcjum Uniwersytetu w Białymstoku i Wojskowej Akademii Technicznej w Warszawie. Stanowił kontynuację rozpoczętych wcześniej badań, ale uzupełnionych o aspekty technologiczne. Świadczyło to o jego interdyscyplinarnym charakterze, jak również było wyrazem ewolucji podejścia do badań w tym obszarze. Zwykle humaniści nie występowali wspólnie z inżynierami w projektach badawczych jako równoprawne strony.

Po raz pierwszy w literaturze polskiej dokonano całościowych analiz etiologii i fenomenologii aktualnych i przyszłych zagrożeń dla bezpieczeństwa obywateli, w szczególności przestępczości zorganizowanej i terroryzmu w wielu ich odmianach. W szczególny sposób potraktowano Internet jako obszar zarówno występowania zagrożeń, jak i miejsca działania organów ścigania i wymiaru sprawiedliwości.

Analizy te stanowiły punkt wyjścia do dokonania oceny adekwatności i skuteczności istniejących regulacji prawnych w zakresie przeciwdziałania i zwalczania przestępczości zorganizowanej i terroryzmu. Wzorem poprzedniego projektu osobno potraktowano zjawisko korupcji oraz sposoby jej przeciwdziałania i zwalczania. Prowadzone analizy obejmowały przede wszystkim regulacje polskie. Jednakże w celu ich wszechstronnej oceny sięgnięto po regulacje innych krajów europejskich oraz z innych części świata oraz regulacje i standardy międzynarodowe.

Istotnym obszarem badań była kwestia oceny legalności stosowania nowych technologii w zakresie przeciwdziałania i zwalczania zagrożeń bezpieczeństwa obywateli. Ponadto przygotowano założenia systemu wykorzystywania nowych tech-

10 Do najważniejszych należą m.in. prace zbiorowe: E.W. Pływaczewski (red.), Przestępczość zorganizowana, świadek koronny, terroryzm - w ujęciu praktycznym, Kraków 2005; K. Indecki (red.), Przestępczość terrorystyczna. Ujęcie praktyczno-dogmatyczne, Poznań-Białystok-Łódź 2006; a także monografie: I. Nowicka, Rozbój drogowy jako przejaw zorganizowanej działalności przestępczej, Kraków 2004; W. Filipkowski, Zwalczanie przestępczości zorganizowanej w aspekcie finansowym, Kraków 2004 oraz K. Laskowska, Rosyjskojęzyczna przestępczość zorganizowana. Studium kryminologiczne, Białystok 2006.

11 Realizowany w latach 2007-2010 pod kierunkiem prof. zw. dr hab. E.W. Pływaczewskiego. 
nologii w pracy operacyjnej oraz procesie karnym dla zapewnienia bezpieczeństwa. Obejmował on następujące rozwiązania technologiczne: bezpieczeństwo sieci teleinformatycznych oraz usług IT, ,inteligentna" wyszukiwarka elektronicznych akt sądowych, technologie komputerowego przetwarzania mowy, zagadnienia związane z systemami agentowymi, metodami sieci społecznych, analizy kompetencji, analizy relacji i powiązań składających się na ogólny problem akwizycji informacji i ekstrakcji wiedzy oraz możliwości zastosowania multimedialnych systemów wspomagających identyfikację i zwalczanie przestępczości.

Oprócz tego wypracowano konkretne postulaty de lege ferenda wraz z uzasadnieniem odnoszące się do konieczności ich wdrożenia oraz prognozą w zakresie skuteczności i poprawy efektywności dotychczasowego systemu. W szczególności przygotowano projekt ustawy o czynnościach operacyjno-rozpoznawczych, który stał się kanwą prac parlamentarnych, a uczestnicy projektu badawczego służyli wiedzą ekspercką w tym zakresie. Niewątpliwą wartością dodaną było także włączenie do badań ponad stu osób: sędziów, prokuratorów, funkcjonariuszy służb - otrzymane wyniki na bieżąco wykorzystywane były i są w praktyce działania tych organów. W ten sposób dyskusje teoretyczne były równoważone zagadnieniami praktycznymi.

Techniczny aspekt projektu również miał wymiar interdyscyplinarny. Obejmował zagadnienia z zakresu od oceny stanu bezpieczeństwa, analizy systemowej i budowania modeli matematycznych oraz biznesowych przez algorytmizację wybranych aspektów, analizę stanu technologicznego, określenie wymagań technologicznych po identyfikację nowych materiałów, konstrukcję czujników i wykorzystanie pojazdów bezzałogowych.

Tytułem podsumowania można wskazać, że ze środków projektu sfinansowano lub zorganizowano 18 konferencji, 7 seminariów i 25 spotkań roboczych. Łącznie w trakcie ich trwania wzięło udział około 4000 uczestników. Wzięli oni udział łącznie w 172 konferencjach, sympozjach i spotkaniach, w tym 64 zagranicznych; wygłosili 135 referatów, w tym 31 w języku obcym. Na dorobek projektu składa się łącznie 401 publikacji ${ }^{12}$ - 195 polskojęzycznych i 72 obcojęzycznych.

Należy wskazać taż na kolejny projekt badawczy zatytułowany „Pozbawianie sprawców owoców przestępstwa” - projekt badawczy (Nr 1049/B/H03/2008/35) ${ }^{13}$. Miał on na celu ocenę skuteczności rozwiązań prawnych dotyczących pozbawiania sprawców owoców przestępstwa w płaszczyźnie postępowania przygotowawczego,

12 Do najważniejszych należały m.in. prace zbiorowe: E.W. Pływaczewski (red.), Current Problems of the Penal Law and the Criminology, Białystok 2009; L.K. Paprzycki, Z. Rau (red.), Praktyczne elementy zwalczania przestępczości zorganizowanej i terroryzmu. Nowoczesne technologie i praca operacyjna, Warszawa 2009; a także monografia E.M. Guzik-Makaruk (red.), Poczucie bezpieczeństwa obywateli w Polsce, Warszawa 2011.

13 Projekt realizowany w latach 2008-2011 przez pracowników Zakładu Prawa Karnego i Kryminologii na Wydziale Prawa Uniwersytetu w Białymstoku. Kierownikiem jest dr hab. E.M. Guzik-Makaruk. 
sądowego i wykonawczego. Jednakże badania ograniczały się tutaj tylko do aspektów prawnych i kryminologicznych zostały poparte zakrojonymi na szeroką skalę badaniami ankietowymi wśród prokuratorów i sędziów.

Poddano analizie poglądy przedstawicieli doktryny (aspekt teoretyczny) i stanowiska praktyki, jak również przeprowadzono badania ankietowe i aktowe funkcjonowania wybranej instytucji na etapie postępowania przygotowawczego, orzekania i wykonania (aspekt empiryczny). Rozważania te zostały wzbogacone o analizy standardów międzynarodowych (zarówno w płaszczyźnie uniwersalnej, jak i regionalnej). Dopiero tak zakreślona problematyka badawcza pozwoliła na sformułowanie postulatów w zakresie interpretacji istniejących rozwiązań, jak i planów co do przyszłych, potencjalnych uregulowań tej kwestii ${ }^{14}$.

$\mathrm{W}$ momencie pisania niniejszego pracowania realizowany jest czwarty w ciągu 10 lat projekt dotyczący bezpieczeństwa pt. „Prawne i kryminologiczne aspekty wdrożenia i stosowania nowoczesnych technologii służących ochronie bezpieczeństwa wewnętrznego" - projekt badawczo-rozwojowy (Nr OR00003707) ${ }^{15}$.

Zakładał on przeprowadzenie badań polegających na wskazaniu kierunków wykorzystywania wiedzy prawniczej i kryminologicznej w zakresie tworzenia rozwiązań technologicznych służących podniesieniu bezpieczeństwa obywateli ${ }^{16}$. $\mathrm{O}$ innowacyjnym charakterze projektu świadczy prowadzenie badań angażujących dwa obszary wiedzy: humanistycznego i technicznego. U podstaw projektu leży założenie, iż analizy kryminologiczne i prawne zawsze powinny poprzedzać wszelkie prace technologiczne w zakresie bezpieczeństwa. To właśnie one muszą wyznaczać obszary, w których wykorzystanie zaawansowanych narzędzi technicznych jest konieczne i dozwolone. Analizy te odnosiły się do bieżącego stanu przestępczości i innych zagrożeń, ale także do określania ich trendów rozwojowych. Jest to podejście proaktywne, nastawione na profilaktykę, uprzedzające działania przestępców. Należy zauważyć, że ci ostatni często korzystają z nowych rozwiązań technicznych, dlatego nie można mieć wątpliwości, iż organy ścigania i wymiaru sprawiedliwości powinny również wykorzystywać ich funkcjonalność. Ponadto, uwzględniając aktualne problemy społeczne i polityczne, obszary badawcze zostały uzupełnione o bezpieczeństwo jądrowe w zakresie zjawiska tzw. „ekoterroryzmu”.

14 Efektem pracy w ramach projektu będzie praca zbiorowa pt. „Przepadek przedmiotów i korzyści pochodzących z przestępstwa” pod redakcją prof. E. M. Guzik-Makaruk, która będzie wydana w 2011 r. przez Wydawnictwo Wolters Kluwer.

15 Projekt realizowany przez Uniwersytet w Białymstoku wspólnie z partnerem komercyjnym PPBW sp. z o.o. od lipca 2009 r. do grudnia 2011 r. Jego kierownikiem jest dr W. Filipkowski.

16 Na dotychczasowy dorobek projektu składają się przyjęte do druku w 2011 prace zbiorowe E.W. Pływaczewski (red.), Przestępczość zorganizowana; W. Filipkowski, W. Mądrzejowski (red.), Biały wywiad oraz monografie P. Chlebowicz, W. Filipkowski, Analiza kryminalna, Aspekty kryminalistyczne i prawnodowodowe, Wydawnictwo Wolters Kluwer i W. Jasiński, Osoby na eksponowanych stanowiskach politycznych. Przeciwdziałanie korupcji i praniu pieniędzy. 
Drugim etapem były badania prawne w zakresie stosowania najnowocześniejszych technologii. Organy ścigania i wymiaru sprawiedliwości - zgodnie z koncepcją demokratycznego państwa prawa - mogą podejmować tylko takie działania, na jakie pozwala im prawo. Badania te odnosiły się nie tylko do oceny bieżącego stanu prawnego, ale także pozwalają poszukiwać nowych rozwiązań (również inspirowanych prawem obcym czy międzynarodowym). Podstawową jednak kwestią było i jest zachowanie zasady proporcjonalności pomiędzy ingerowaniem w prawa człowieka i obywatela (za pomocą rozwiązań technologicznych) i ich ochroną w państwie demokratycznym. Jest to dylemat obecny w wielu dyskusjach prowadzonych w społeczeństwie, mediach i oczywiście środowisku akademickim ${ }^{17}$.

Badania techniczne zajmowały trzeci obszar badawczy. Ich podstawowym zadaniem było sprawdzenie, czy istniejące rozwiązania mogą być dostosowane do potrzeb organów ścigania i wymiaru sprawiedliwości, spełniając wymogi dowodowe postępowania karnego czy pracy operacyjnej. Wybrane zostały takie technologie, wobec których można oczekiwać tej potencjalnej przydatności, gdyż odpowiadają potrzebom organów ścigania. Należą do nich: gromadzenie i analizowanie informacji, monitoring audiowizualny, lokalizowanie przedmiotów. Należy dodać, iż są to tzw. technologie podwójnego zastosowania, czyli mogą znaleźć swoje miejsce na rynku komercyjnym, cywilnym. Zaawansowane technologie funkcjonujące na rzecz bezpieczeństwa do tej pory nie doczekały się pogłębionej analizy prawniczej i kryminologicznej. Był to element spajający cały projekt. Problematyka tzw. białego wywiadu oraz pranie pieniędzy pochodzących z korupcji osób na eksponowanych stanowiskach politycznych były szczególnymi zagadnieniami poddanymi analizie. Wzorem poprzednich lat, projekt zakładał szerokie wykorzystanie konsultantów pochodzących z organów ścigania i wymiaru sprawiedliwości w celu uzyskania większej efektywności i użyteczności prowadzonych badań.

Po czwarte, projekt zakładał także komercyjne wykorzystanie wyników prowadzonych badań. Zakładano powstanie podmiotu gospodarczego, który miał świadczyć usługi w zakresie objętym badaniami. Na potrzeby projektu została określona jego funkcja jako tzw. brokera informacji, czyli podmiotu dostarczającego informacji zainteresowanym podmiotom. Już w momencie pisania niniejszego opracowania można ocenić, iż jest on zdolny do informowania o potrzebach organów ścigania i wymiaru sprawiedliwości (np. w postaci konferencji, szkoleń, udziału w targach), które to informacje mogą zostać wykorzystane przez inne podmioty gospodarcze, a tym samym przyczynić się do rozwoju tej gałęzi gospodarki. Podmiot gospodarczy będzie też oferował niektóre produkty wytworzone w oparciu o rozwijane technologie.

17 Przykładem europejskiego projektu zajmującego się różnymi aspektami tego zagadnieniem jest wymieniany wcześniej DETECTER. 
Komercjalizacja wyników badań naukowych jest kolejnym etapem ewolucji kierunków badań z zakresu bezpieczeństwa i porządku publicznego. Zakłada ona, iż wyniki uzyskane w projekcie należy analizować pod kątem tego, czy mogą one stanowić wkład do produktów lub usług oferowanych na rynku. Ich wartość leży często $\mathrm{w}$ innowacyjności wytwarzanych lub rozwijanych technologii, co jest szansą na podniesienie konkurencyjności produktów lub usług oferowanych przez podmioty gospodarcze. W celu osiagnięcia tego efektu należy do projektów zapraszać podmioty gospodarcze, które ze swej natury mają lepsze od naukowców rozeznanie, czy uda się daną technologię skomercjalizować.

Zaprezentowaną powyżej ewolucję prowadzenia badań naukowych w obszarze bezpieczeństwa można przedstawić na poniższym diagramie.

Diagram nr 1. Ewolucja badań nad bezpieczeństwem

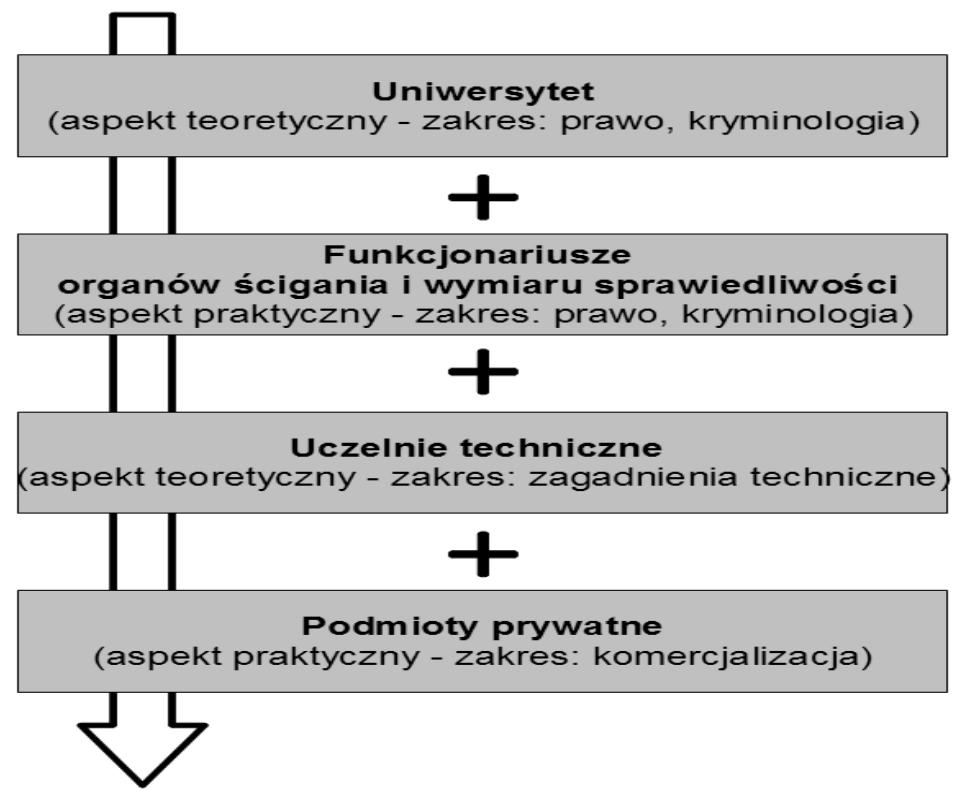

Źródło: opracowanie własne.

\section{Narodowe Centrum Badań i Rozwoju}

Pewnym wskaźnikiem obszarów zainteresowania administracji publicznej są tematy konkursów ogłaszanych przez Narodowe Centrum Badań i Rozwoju doty- 
czących m.in. badań nad bezpieczeństwem i obronnością państwa ${ }^{18}$. Są one przedstawiane przez resorty odpowiedzialne za zapewnienie bezpieczeństwa, porządku publicznego oraz obronności, a także poszczególne organy państwowe (zwłaszcza służby specjalne).

Ogłoszenie z sierpnia br. zawierało bardzo zróżnicowane 32 tematy ${ }^{19}$. Na potrzeby niniejszego opracowania można dokonać pewnego ich uporządkowania tematycznego:

1. Technologiczne aspekty podnoszenia efektywności działań z zakresu zarządzania kryzysowego dotyczących zarówno katastrof naturalnych (pożarów, powodzi), jak i np. terroryzmu

- Opracowanie nowoczesnych stanowisk szkoleniowych zwiększających skuteczność działań ratowników Krajowego Systemu Ratowniczo-Gaśniczego (KSRG).

- Optymalizacja procedur, dyslokacji baz i doskonalenie rozwiązań technicznych sprzętu stosowanego przez polskie służby ratownicze w zakresie przeciwdziałania zagrożeniom naturalnym ze szczególnym uwzględnieniem powodzi (rękawy przeciwpowodziowe).

- Symulator kierowania pojazdami uprzywilejowanymi podczas działań typowych i ekstremalnych.

- Zaawansowane technologie teleinformatyczne wspomagające zarządzanie kryzysowe i ratownictwo w jednostkach terytorialnych Rzeczypospolitej Polskiej oraz w jednostkach organizacyjnych Państwowej Straży Pożarnej.

- Zwiększenie bezpieczeństwa pożarowego obiektów budowlanych poprzez opracowanie nowoczesnego systemu monitoringu pożarowego na terenie Rzeczypospolitej Polskiej.

- Poprawa bezpieczeństwa pożarowego budynków i obiektów budowlanych na etapie ich projektowania i wykonania.

- Opracowanie innowacyjnego środka przeznaczonego do usuwania zanieczyszczeń i skażeń z infrastruktury drogowej oraz przemysłowej.

- Technologie zabezpieczeń przeciwwybuchowych miejsc składowania materiałów sypkich. 
- Zintegrowany system informacyjny wspomagający działania antyterrorystyczne Centrum Antyterrorystycznego Agencji Bezpieczeństwa Wewnętrznego.

2. Badania kryminalistyczne

- Zaprojektowanie mobilnej platformy do wsparcia badań kryminalistycznych miejsc zdarzeń, w których może występować zagrożenie $\mathrm{CBRN}^{20}$.

- Mobilne laboratorium do poboru próbek środowiskowych i identyfikacji zagrożeń biologicznych.

- Opracowanie na potrzeby wymiaru sprawiedliwości ilościowych i jakościowych metod identyfikacji nowych substancji objętych kontrolą na mocy ustawy o przeciwdziałaniu narkomanii.

- Dostosowanie nowych narzędzi biologii molekularnej do identyfikacji sprawców przestępstw.

- Zastosowanie nowych odczynników chemicznych do ujawniania śladów daktyloskopijnych na różnych podłożach metodą luminescencji opóźnionej w zakresie promieniowania od UV do NIR.

- Opracowanie metody replikacji śladów kryminalistycznych.

- Opracowanie technologii namiotu do ujawniania śladów parami estru kwasu cyjanoakrylowego.

- Projektowanie badań empirycznych i analizy materiałów dotyczących specyfiki metod kryminalistyki w pracy służb specjalnych służ porządku publicznego.

3. Zarządzanie i ochrona informacji, w szczególności w sieci

- Autonomiczne narzędzia wspomagające zwalczanie cyberprzestępczości.

- Wypracowanie modelu uwierzytelniania i autoryzacji użytkowników, w tym użytkowników pozapolicyjnych oraz metody bezpiecznego dostępu do zasobów IT Policji z różnych sieci, z uwzględnieniem sieci internetowej.

- System zarządzania bezpieczeństwem teleinformatycznym jednostek administracji publicznej oraz resortu obrony narodowej, wraz z narzędziami wspomagającymi zwalczanie cyberterroryzmu i ochronę teleinformatycznej infrastruktury krytycznej. 
- Ochrona informacji istotnych dla bezpieczeństwa i funkcjonowania państwa, w tym o klauzuli „Ściśle Tajne” - Budowy narodowego centrum kryptografii i dekryptażu.

- System akustycznej platformy pomiarowej dla potrzeb bezpieczeństwa informacji stworzony $\mathrm{z}$ wykorzystaniem interferometrycznej metody pomiaru drgań.

- Techniki biometryczne oraz PKI w nowoczesnych dokumentach tożsamości i ochronie systemów informacyjnych.

4. Podniesienie efektywności funkcjonowania organów ścigania i wymiaru sprawiedliwości przy pomocy rozwiązań technologicznych - aspekty prawne, kryminologiczne i kryminalistyczne

- Nowoczesne technologie dla/w procesie karnym i ich wykorzystanie aspekty techniczne, kryminalistyczne, kryminologiczne i prawne.

- Opracowanie systemu wykrywania zagrożeń bezpieczeństwa osób niewidomych i słabowidzących ze szczególnym uwzględnieniem ruchu drogowego. Aspekty prawno-kryminologiczne i technologiczne.

- Zaawansowane technologie informatyczne wspierające procesy przetwarzania danych w obszarze analizy kryminalnej.

5. Badania z zakresu obronności na potrzeby wojska

- Mobilna, trójwspółrzędna stacja radiolokacyjna dalekiego zasięgu pracująca w paśmie $S$.

- Dywizjonowy moduł ogniowy $155 \mathrm{~mm}$ armatohaubic samobieżnych.

- Opracowanie małego bezpilotowego wiropłata.

6. Bezpieczeństwo osobiste

- Nowoczesna, trudnopalna i ergonomiczna kamizelka balistyczna skrytego noszenia.

- Nowoczesne ochrony osobiste służb ratowniczych KSRG w oparciu o potrzeby użytkowników końcowych.

7. Bezpieczeństwo granic

- Opracowanie metod i technologii wspomagania ochrony perymetrycznej terenów granicznych i portów lotniczych w oparciu o zaawansowaną analizę sygnałów akustycznych i obrazów wizyjnych. 


\section{Proponowane kierunki badań}

Tytułem podsumowania - po przeprowadzeniu prezentacji dotychczasowych obszarów badawczych - należy wskazać najbardziej obiecujące. Zaprezentowana lista wynika z oceny bieżącej sytuacji społecznej, zapotrzebowania organów ścigania wymiaru sprawiedliwości oraz praktycznego doświadczenia, jakie jest udziałem zespołu badawczego Katedry Prawa Karnego Wydziału Prawa Uniwersytetu w Białymstoku.

Wskazać należy następujące obszary badawcze:

- Badania dogmatyczne nad koniecznością i sposobem uregulowania zjawisk społecznych, które do tej pory nie doczekały się efektywnego instrumentarium prawnego oraz zupełnie nowych związanych z rozwojem społeczeństwa, powstającymi patologiami oraz osiagnięciami technologicznymi. Prawo pozostaje najpoważniejszym narzędziem państwa w zakresie regulowania zachowań ludzi i ich grup. Pozostaje tylko pytanie o zakres takiego sterowania.

- Badania wielopłaszczyznowe, kompleksowe nad zjawiskami społecznymi wymienionymi w poprzednim punkcie. Nie można już podchodzić do rozwiązywani tych problemów w sposób jednostronny. Należy wykorzystać efekt współpracy i synergii wysiłków naukowców i praktyków pochodzących z różnych środowisk humanistycznych czy też technicznych dla rozwiązywania problemów społecznych.

- Badania z zakresu partnerstwa publiczno-prywatnego na rzecz zapewnienia bezpieczeństwa. Zmniejszenie uprawnień organów ochrony porządku publicznego i bezpieczeństwa lub zmniejszenie im środków finansowych czy osobowych spowoduje, że w to miejsce w sposób naturalny wejdą (już jest to widoczne) podmioty prywatne (komercyjne - firmy ochrony osób i mienia oraz typu non-profit - np. straże sąsiedzkie). Zachodzi konieczność określenia zakresu ich uprawnień oraz relacji z organami państwowymi, samorządem lokalnym etc. W zakresie tym mieści się także kwestia komercjalizacji wyników badań naukowych w zakresie bezpieczeństwa.

- Lepsze wykorzystanie informacji dostępnej powszechnie - w zakresie pozyskiwania, gromadzenia, ewaluacji, wykorzystania - w szczególności Internetu i mediów społecznych (np. monitoring i przewidywanie zdarzeń na podstawie wpisów na portalach społecznościowych). Każdy, kto obserwuje rzeczywistość, uzna ten punkt za truizm, ale w zasadzie należy zadać sobie pytanie, jak dużo tego typu badań w zasadzie jest prowadzonych obecnie? Czy są one aktualne? Czy w ogóle nadążają one za zmieniającym się społeczeństwem informacyjnym? 
- Integracja baz danych i systemów informatycznych poszczególnych służb oraz pomiędzy służbami - celem zmniejszenia kosztów ich funkcjonowania oraz zwiększenia współpracy organów państwowych. Należy w końcu przekuć w czyn stwierdzenie, że żyjemy w społeczeństwie informacyjnym, a informacja jest najbardziej pożądanym towarem i orężem zapewniającym bezpieczeństwo i porządek publiczny.

- Zwiększenie interoperacyjności poszczególnych rozwiązań informatycznych oferowanych przez różnych dostawców organom państwowym, np. poprzez standaryzację protokołów wymiany informacji, zautomatyzowanie akwizycji, gromadzenia, analizowania i wykorzystywania informacji zawartych w bazach prywatnych i państwowych. 


\section{НОВЫЕ НАПРАВЛЕНИЯ ИССЛЕДОВАНИЙ БЕЗОПАСНОСТИ В ПОЛЬШЕ И ИХ РЕЗУЛЬТАТЫ}

Вработеосвещаютсяновыенаправленияюридических, криминологических и криминалистических исследований в области безопасности. Проблема рассматривается на примере проектов, реализованных в последние годы на юридическом факультете Университета в Белостоке. Кроме того, на основе анализа тематики конкурсов, объявленных в 2011 г. вновь созданным Национальным центром исследований и развития, указываются существующие в настоящее время в Польше тенденции в данной области знаний. Отмечается необходимость проведения междисциплинарных исследований, посвященных текущим и будущим угрозам безопасности и общественному порядку. Они должны в большей мере привлекать не только теоретиков, но и практических работников органов следствия, спецслужб и органов правосудия. Особое значение придается сотрудничеству с субъектами, коммерциализирующими результаты таких исследований, что соответствует Лиссабонской стратегии. По всей вероятности, новые технологические решения смогут значительно улучшить ситуацию в сфере обеспечения безопасности и общественного порядка. В заключение автором предложены направления исследований, объединяющих право, криминалистику и технологии. 
NEW DIRECTIONS OF SECURITY RESEARCH IN POLAND AND THEIR EFFECTS

The present study discusses new directions of research - legal, criminological and in the sphere of criminalistics - on security. This area of research was the subject of numerous projects realized at the Law Faculty of Bialystok University in the recent years. Furthermore an analysis of the subject areas for research to be sponsored by the newly created National Centre for Research and Development in 2011 revealed the trends in development that are visible in Poland at present. The need to conduct interdisciplinary research corresponding to current and future threats to security and the public order was also noted. These efforts should engage increased involvement from theoreticians but also from practitioners of law enforcement, the secret services and organs for the administration of justice. It is also of importance to cooperate with entities commercializing the results of such research, which is consistent with the Lisbon Strategy. In addition new technological advances could provide significant facilitation and improvement in ensuring security and public order. The author of the study, in summing up, suggested lines of research connecting law, criminalistics and technology.

Key words:

Interdisciplinary research, security, public order, law enforcement 